\title{
C-Silylated Calix[4]Arene as a New Receptor for Aspartate in Polar Solvents
}

\author{
Reza Zadmard, Parinaz Ataeian, and Maryam Khalili-Foumeshi \\ Department of Organic Chemistry, Chemistry and Chemical Engineering Research Center of Iran, P.O. Box: 14335-186, \\ Tehran 14968-13151, Iran \\ Correspondence should be addressed to Reza Zadmard, zadmard@ccerci.ac.ir
}

Received 9 April 2011; Accepted 23 May 2011

Academic Editor: Ken Shimizu

Copyright ( 92011 Reza Zadmard et al. This is an open access article distributed under the Creative Commons Attribution License, which permits unrestricted use, distribution, and reproduction in any medium, provided the original work is properly cited.

The recognition of aspartic acid derivatives such as N-benzyloxycarbonyl-D-aspartate (NZDA) with the calix[4] arene derivatives with multiple silicon groups at the upper rim in polar solvents is investigated.

\section{Introduction}

The development of synthetic receptors for a chosen substrate (host-guest chemistry) is a well-established area of research, and selective receptors have now been described for a whole range of substrates, from simple metal cations to polyfunctional molecules such as peptides, proteins, and carbohydrates $[1,2]$. Carboxylic acids (or carboxylates) are a particularly common functional group in biological and synthetic organic molecules and have inspired the elaboration of a number of different approaches for their recognition. Binding sites have been developed both for simple carboxylic acids and for incorporation into sophisticated receptors for more complex carboxylic acid derivatives, both in polar and nonpolar solvents [3].

The development of synthetic receptors for enantioselective binding of L-glutamate and L-aspartate derivatives has been of particular interest because of the critical role of these amino acids in the central nervous system as excitatory transmitters. Several groups have successfully developed receptors to be able to bind a range of dicarboxylates [4-6].

Calixarenes have been widely studied as hosts and potential hosts for molecular recognition [7]. For example, the binding affinities between $p$-tert-butylcalix[4] arene-based dipodal and some aliphatic diacetates such as malonate, succinate, glutarate, adipate, pimelate, and suberate in $\mathrm{CH}_{3} \mathrm{CN}$ were studied by Singh et al. [8]. We have recently introduced a different type of substituted calix[4]arene derivatives, which have a multiple functional groups at the upper rim. These receptors can bind selective amino acids such as arginine and lysine in polar solvents [9]. The recognition of aspartitic acid derivatives such as N-benzyloxycarbonyl-Daspartate (NZDA) with the calix[4] arene derivatives with multiple silicon groups at the upper rim is investigated.

\section{Results and Discussion}

2.1. Synthesis. Disilylated calixarene, 6 and 7 were synthesized according to the following procedure (Figure 1).

The main synthetic route starts from $n$-butyl-protected free calix [4] arene $\mathbf{1}[10,11]$ which is butylated in one pot to give 2 [12]. Partial butylation of 1 afforded 3 in good yield [13].

The tetrabromo derivative $\mathbf{4}$ and dibromo derivative $\mathbf{5}$ can be prepared with the NBS bromination and subsequently butylation [14]. After bromine-lithium exchange on 4 and 5 with $\mathrm{Li}$ powder proceeds smoothly, the phenyllithium intermediate is then efficiently trapped by trimethylsilyl chloride (TMSCl) that give the disilylated derivatives $\mathbf{6}$ and $7[15,16]$.

\section{Binding Experiments}

The compounds $\mathbf{6}$ and 7 were selected for preliminary study of host-guest properties in chloroform and methanol $(1: 1)$ at $25^{\circ} \mathrm{C}$. To evaluate the binding ability of calix[4] arene 
TABLE 1: Association constants between various receptors and NZDA 8 and aspartic acid 9.

\begin{tabular}{lcccc}
\hline Entry & Receptor & Guest & $K_{a}\left(\mathrm{M}^{-1}\right)^{4}$ & Stoich. \\
\hline 1 & $\mathbf{4}$ & NZDA $\mathbf{8}$ & $1000( \pm 4 \%)$ & $1: 1$ \\
2 & $\mathbf{6}$ & NZDA $\mathbf{8}$ & $5000( \pm 6 \%)$ & $1: 1$ \\
3 & $\mathbf{7}$ & NZDA $\mathbf{8}$ & $6000( \pm 10 \%)$ & $1: 1$ \\
4 & $\mathbf{1 0}$ & NZDA $\mathbf{8}$ & $2000( \pm 6 \%)$ & $1: 1$ \\
5 & $\mathbf{1 1}$ & NZDA $\mathbf{8}$ & $20000( \pm 10 \%)$ & $2: 1$ \\
\hline 6 & $\mathbf{4}$ & Aspartic acid $\mathbf{9}$ & $700( \pm 7 \%)$ & $1: 1$ \\
7 & $\mathbf{6}$ & Aspartic acid $\mathbf{9}$ & $3000( \pm 8 \%)$ & $1: 1$ \\
8 & $\mathbf{7}$ & Aspartic acid $\mathbf{9}$ & $900( \pm 11 \%)$ & $1: 1$ \\
9 & $\mathbf{1 0}$ & Aspartic acid $\mathbf{9}$ & $300( \pm 8 \%)$ & $1: 1$ \\
10 & $\mathbf{1 1}$ & Aspartic acid $\mathbf{9}$ & $5000( \pm 4 \%)$ & $1: 1$ \\
\hline
\end{tabular}

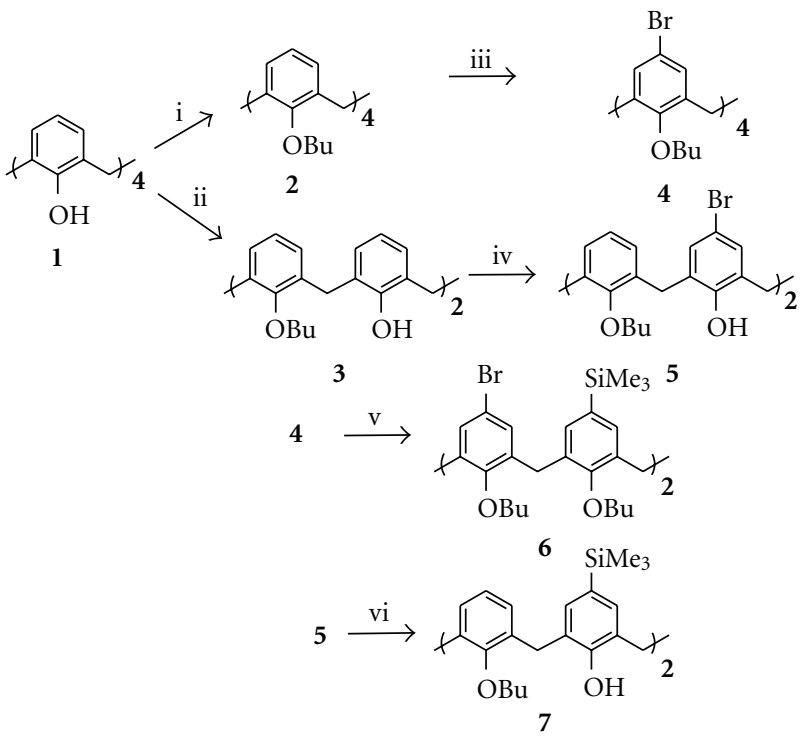

Figure 1: Synthetic route to calix[4] arene receptos 6/7; (i) BuBr, $\mathrm{NaH}$, dry DMF, (ii) $\mathrm{BuBr}, \mathrm{K}_{2} \mathrm{CO}_{3}$, (iii) NBS, MEK, (iv) NBS, MEK, $\mathrm{K}_{2} \mathrm{CO}$, (v) and (vi) Li powder, THF. $-78^{\circ} \mathrm{C}, \mathrm{TMSCl}$.

receptors 6 and 7 towards different aspartate anions, UVvis experiments were carried out. The anion recognition via the formation of stable hypercoordinate complexes between the anion and the silylated calixarenes can be easily monitored by anion-complexation induced changes in UVvis spectra. The stoichiometries of the complexes formed between the anions and the host were determined from Job's plot.

The aspartate derivative, N-benzyloxycarbonyl-D-aspartate (NZDA) 8, $\left(10^{-4} \mathrm{M}\right)$ shows an absorption band at $265 \mathrm{~nm}$ in the UV spectrum in the absence of receptors. Upon increasing amounts of receptor $\mathbf{6}$ in the solution of NZDA 8, a marked increase in UV intensity was observed. This indicates a strong interaction with an association constant $5 * 10^{3} \mathrm{M}^{-1}$, and producing a sharply kinked titration curve (Figure 2).

For the determination of complex stoichiometry between receptor 6/NZDA 8, we have used the job methods [17]. The resulting plot shows an approximate $1: 1$ stoichiometry (Figure 3).
Table 1 shows the binding constant and stoichiometry between NZDA 8 and aspartic acid $\mathbf{9}$ and different calix[4] arene receptors.

The results show that receptor 7 has a good affinity to the NZDA 8. (Table 1 entry 3), in comparison to the latter interaction, the association constant between receptors 6 and 8 decreases because of the steric effect of bromine groups at the upper rim of $\mathbf{6}$. The binding affinities of $\mathbf{6}$ and 7 for NZDA 8 are greater than the affinities of $\mathbf{6}$ and 7 for aspartic acid (Table 1 entry 2, 3 and 7,8 ). The receptors 4 and 10, which have not silyl group at the upper rim, could bind aspartate and aspartic acid weaker than receptors 6 and 7. This may be due to the formation of hypercoordinate complexes between the guests and silylated host (6 and 7), (Figure 2). In the case of receptor 11, it is believed that the electrostatic interaction is the main interaction (Figure 4).

\section{Experimental Section}

4.1. General Remarks. All reagents were purchased at highest commercial grade and used as supplied. All solvents were dried over molecular sieve. Anhydrous solvents were distilled 


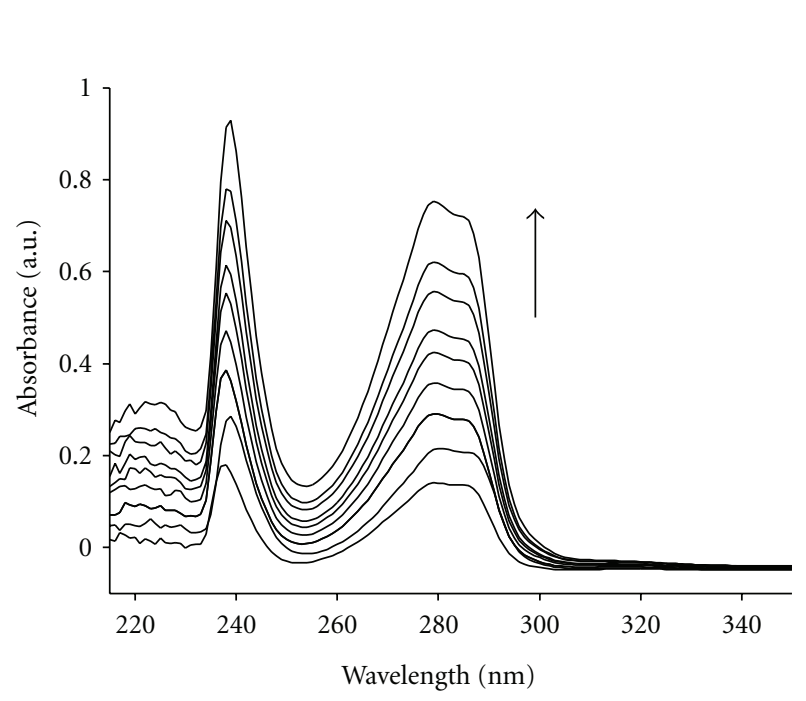

(a)

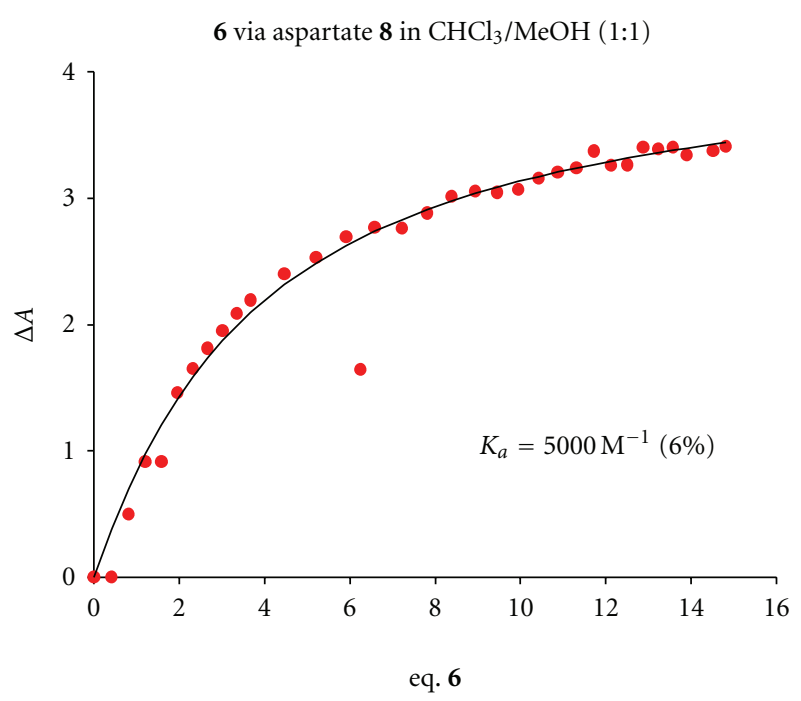

(b)

FIGURE 2: UV enhancing and resulting titration curve for the interaction of 6 with NZDA $\left(\mathrm{CHCl}_{3} / \mathrm{MeOH} 1: 1\right)$.

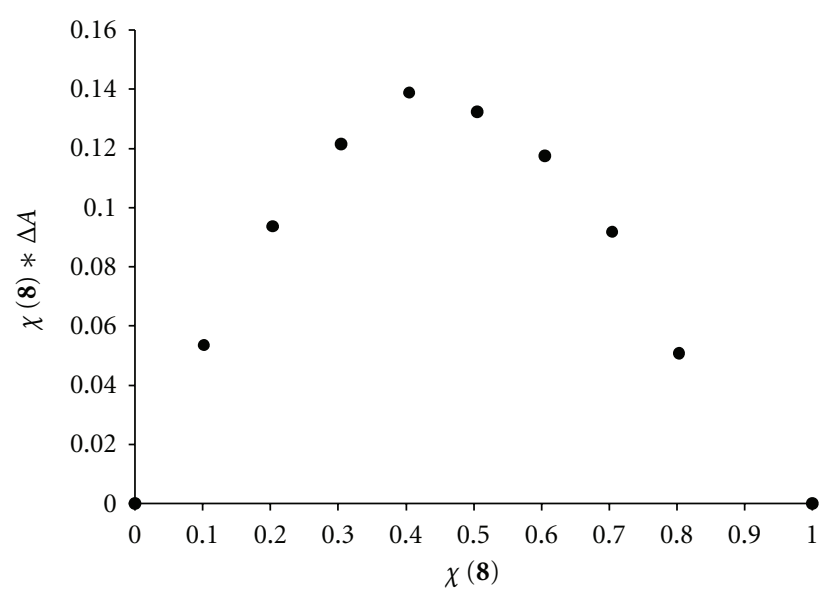

Figure 3: Job plot between 6 and NZDA $\left(\mathrm{CHCl}_{3} / \mathrm{MeOH} 1: 1\right)$.

from the following drying agents: acetonitrile (calcium hydride), dichloromethane (calcium hydride), and methanol (magnesium). Reactions were monitored by thin layer chromatography (TLC) with Merck silica gel 60 F254 plates. Silica gel 60 for flash chromatography (particle size 230400 mesh) was supplied by Merck. Yields refer to chromatographically and spectroscopically pure compounds unless otherwise noted. Melting points were determined on a Büchi melting point apparatus B545 and are uncorrected. ${ }^{1} \mathrm{H}$ and ${ }^{13} \mathrm{C}$ spectra were recorded at $300 \mathrm{~K}$ on a Bruker Avance DMX 300 or DRX 500 spectrometer. Chemical shifts are reported as $\delta$ values in ppm and calibrated on the particular solvent signal; multiplicities are indicated by s (singlet), $\mathrm{d}$ (doublet), $\mathrm{t}$ (triplet), $\mathrm{m}$ (multiplet), and br (broad). ${ }^{13} \mathrm{C}$ spectra are broadband decoupled and calibrated on the particular solvent signal. High-resolution electron spray ionisation (ESI) mass spectra were recorded on a MAT $95 \mathrm{~S}$ Finnigan spectrometer. Samples $(20 \mu \mathrm{L})$ were introduced as $10^{-7} \mathrm{M}$ solutions in HPLC-grade methanol at flow rates of
$20 \mu \mathrm{L} \cdot \mathrm{min}^{-1}$; heated capillary temperature: $150^{\circ} \mathrm{C}$; ion spray potential: $3.5 \mathrm{kV}$ (positive ESI), $3.0 \mathrm{kV}$ (negative ESI). About 20-30 scans were averaged to improve the signal to noise ratio. UV-vis experiments were performed on an Agilent $8453 \mathrm{E}$ unit. Helma cuvettes with $0.2 \mathrm{~mm}$ inner diameter were used for the experiments.

4.2. Synthesis of 5,17-Bis(trimethylsilyl)-11,23-dibromo-25,26, 27,28-tetra-butoxy-calix[4]arene 6. The synthesis of the tetrabromocalixarene 4 and dibromocalixarene 5 starts with butylation of the parent calixarene $\mathbf{1}$, followed by bromination according to the literature [13-16].

A solution of 5,11,17,23-tetrabromo-25,26,27,28-tetrabutoxy Calix[4]arene(4) $(0.25 \mathrm{~g}, 0.26 \mathrm{mmol})$ in dry THF $(5 \mathrm{~mL})$ was stirred under argon and cooled to $-78^{\circ} \mathrm{C}$. Then butyllithium $1.6 \mathrm{M}$ in hexane $(0.033 \mathrm{~g}, 0.52 \mathrm{mmol})$ was added dropwise, and the mixture was stirred for $0.5 \mathrm{~h}$ at $-78^{\circ} \mathrm{C}$, and $1.5 \mathrm{~h}$ at room temperature. Again the solution cooled to $-65^{\circ} \mathrm{C}$ and to the mixture was added dropwise 


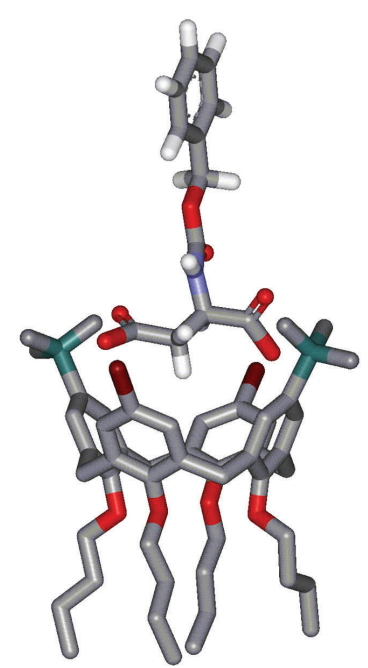

(a)

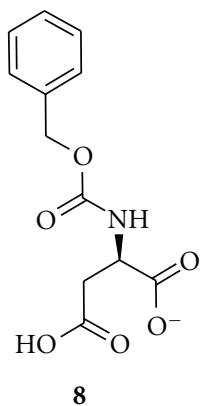<smiles>CCCOc1c(C)cc(C(C)(C)C)cc1CC</smiles>

(b)

FIgURE 4: The complex structure between $\mathbf{6}$ and $\mathbf{8}$. Lewis structure of $\mathbf{8 , 1 0}$, and 11 .

trimethylchlorosilane. The result solution was stirred at room temperature for $12 \mathrm{~h}$, and then the reaction mixture was refluxed for $2 \mathrm{~h}$. The mixture was washed with $10 \mathrm{~mL}$ of saturated ammoniumchlorid. The organic layer was separated, dried over sodium sulfate, and the solvent was removed under reduced pressure. The purification of the residue by column chromatography (pet. ether/ethyl acetate, 99: 1) gave $0.06 \mathrm{~g}(24 \%)$ of 6 .

${ }^{1} \mathrm{H}-\mathrm{NMR}(500 \mathrm{MHz}, \mathrm{CDCl} 3): \delta=0.16(\mathrm{~S}, 18 \mathrm{H}, \mathrm{SiMe} 3)$, $0.91(\mathrm{t}, 6 \mathrm{H}, J=7 \mathrm{~Hz}), 0.96(\mathrm{t}, 6 \mathrm{H}, J=7 \mathrm{~Hz}), 1.86(\mathrm{~m}, 8 \mathrm{H}, J=$ $7 \mathrm{~Hz}), 2.12(\mathrm{~m}, 8 \mathrm{H}, J=7 \mathrm{~Hz}), 3.45(\mathrm{~d}, 4 \mathrm{H}, J=13 \mathrm{~Hz}), 4.09(\mathrm{t}$, $8 \mathrm{H}, J=7 \mathrm{~Hz}), 4.40(\mathrm{~d}, 4 \mathrm{H}, J=13 \mathrm{~Hz}), 6,21(\mathrm{~s}, 4 \mathrm{H}), 7.21(\mathrm{~s}$, $4 \mathrm{H})$.

${ }^{13} \mathrm{C} \mathrm{NMR}\left(75 \mathrm{MHz}, \mathrm{CDCl}_{3}\right): \delta=1.44,10.73,14.42,19.68$, $23.71,31.16,31.51,31.89,32.49,115.59,125.28,131.43$, $134.25,136.89,155.98$.

TOF-MS (ESI-positive): Calcd for $\mathrm{C}_{50} \mathrm{H}_{70} \mathrm{Br}_{2} \mathrm{O}_{4} \mathrm{Si}_{2}, \mathrm{~m} / \mathrm{z}$ $=951.0674\left(\mathrm{M}^{+}\right)$.found: 951.3159 .

4.3. Synthesis of 5,17-Bis(trimethylsilyl)-25,27-dibutoxy-calix [4]arene 7. A stirred activated $\mathrm{Li}$ powder $(0.01632 \mathrm{~g}$, $2.4 \mathrm{mmol})$ in dry THF $(3 \mathrm{ml})$ was cooled to $-78^{\circ} \mathrm{C}$ and was stirred vigorously under argon for $30 \mathrm{~min}$ in $-78^{\circ} \mathrm{C}$. Then a solution of 5,17-dibromo-25,27-dibutoxy calix[4] arene $\mathbf{5}$ $(0.38 \mathrm{~g}, 0.39 \mathrm{mmoL})$ in dry $\mathrm{THF}(10 \mathrm{~mL})$ was added dropwise, and the mixture was stirred for $0.5 \mathrm{~h}$ at $-78^{\circ} \mathrm{C}$. After warming to room temperature, the mixture was stirred at room temperature for $2 \mathrm{~h}$. Then trimethylchlorosilane $(0.8 \mathrm{~mL}, \mathrm{mmoL})$ was added dropwise to the mixture, and the reaction was continued for $12 \mathrm{~h}$. After this time, the suspense dark precipitate was filtered. Then, the filtrate was heated to reflux for $1.5 \mathrm{~h}$, and after cooling, the mixture was evaporated under reduced pressure. The residue is then dissolved in the minimum amount of $\mathrm{CH}_{2} \mathrm{Cl}_{2}$, and, to this solution, $\mathrm{MeOH}$ was dropwise added till further addition leads to turbidity and the obtained solution was let in $-15^{\circ} \mathrm{C}$ for overnight. The obtained pure 5,17-bis(trimethylsilyl)-25,27-dibutoxy calix[4] arene(7) crystals $(0.3 \mathrm{~g}, 78 \%)$ was filtered.
${ }^{1} \mathrm{H} \mathrm{NMR}\left(500 \mathrm{MHz}, \mathrm{CDCl}_{3}\right): \delta=0.16\left(\mathrm{~s}, 18 \mathrm{H}, \mathrm{SiMe}_{3}\right)$, $0.96(\mathrm{t}, 6 \mathrm{H}, J=6.3 \mathrm{HZ}), 1.86(\mathrm{~m}, 4 \mathrm{H}), 2.12(\mathrm{~m}, 4 \mathrm{H}), 3.45(\mathrm{~d}$, $4 \mathrm{H}, J=12.95 \mathrm{~Hz}), 4.09(\mathrm{t}, 4 \mathrm{H}, J=6.3 \mathrm{HZ}), 4.40(\mathrm{~d}, 4 \mathrm{H}, J=$ $12.95 \mathrm{~Hz}), 7.00(\mathrm{~m}, 10 \mathrm{H}), 8.31(\mathrm{~s}, 2 \mathrm{H}, \mathrm{OH})$.

${ }^{13} \mathrm{C} \mathrm{NMR}\left(75 \mathrm{MHz}, \mathrm{CDCl}_{3}\right): \delta=1.45,14.52,14.55,19.84$, $23.13,29.80,30.14,31.68,31.87,32.37,32.70,76.96,119.31$, $119.38,123.63,125.68,128.60,128.84,129.33,130.15$, $133.90,152.42,153.80$.

TOF-MS (ESI-positive): Calcd for $\mathrm{C}_{50} \mathrm{H}_{72} \mathrm{O}_{4} \mathrm{Si}_{2}, \mathrm{~m} / \mathrm{z}=$ $792.4669\left(\mathrm{M}^{+}\right)$.found: 792.4344 .

\section{Conclusions}

It is possible to recognize N-benzyloxycarbonyl-D-aspartate (NZDA) 8 with silylated calix[4] arene 6 and 7, in polar solvent. The investigation shows that the silyl groups at upper calix[4]arene have great effect on binding process. Since NZDA is very similar to NMDA, as a channel blocker, the further studies could lead to introducing these new generation receptors $\mathbf{6}$ and $\mathbf{7}$ for clinically favorable NMDA receptor.

\section{Acknowledgment}

Partial financial support by the Ministry of Science, Research, and Technology of Iran is greatly appreciated.

\section{References}

[1] J. H. Hartley, T. D. James, and C. J. Ward, "Synthetic receptors," Journal of the Chemical Society, Perkin Transactions 1, no. 19, pp. 3155-3184, 2000.

[2] P. D. Beer and P. A. Gale, "Anion recognition and sensing: the state of the art and future perspectives," Angewandte Chemie International Edition, vol. 40, no. 3, pp. 486-516, 2001.

[3] R. J. Fitzmaurice, G. M. Kyne, D. Douheret, and J. D. Kilburn, "Synthetic receptors for carboxylic acids and carboxylates," Journal of the Chemical Society. Perkin Transactions 1, no. 7, pp. 841-864, 2002. 
[4] P. Blondeau, M. Segura, R. Pérez-Fernández, and J. De Mendoza, "Molecular recognition of oxoanions based on guanidinium receptors," Chemical Society Reviews, vol. 36, no. 2, pp. 198-210, 2007.

[5] K. A. Schug and W. Lindner, "Noncovalent binding between guanidinium and anionic groups: focus on biologicaland synthetic-based arginine/guanidinium interactions with phosph[on] ate and sulf[on] ate residues," Chemical Reviews, vol. 105, no. 1, pp. 67-113, 2005.

[6] M. D. Best, S. L. Tobey, and E. V. Anslyn, "Abiotic guanidinium containing receptors for anionic species," Coordination Chemistry Reviews, vol. 240, no. 1-2, pp. 3-15, 2003.

[7] C. D. Gutsche, "Calixarenes," in Monographs in Supramolecular Chemistry, The Royal Society of Chemistry, London, UK, 1989.

[8] N. Singh, G. W. Lee, and D. O. Jang, "p-tert-Butylcalix [4] arene-based fluororeceptor for the recognition of dicarboxylates," Tetrahedron, vol. 64, no. 7, pp. 1482-1486, 2008.

[9] R. Zadmard, M. Arendt, and T. Schrader, "Multipoint recognition of basic proteins at a membrane model," Journal of the American Chemical Society, vol. 126, pp. 7552-7553, 2004.

[10] C. D. Gutsche, M. Iqbal, and D. Stewart, "Calixarenes. 18. Synthesis procedures for p-tert-butylcalix[4] arene," Journal of Organic Chemistry, vol. 51, no. 5, pp. 742-745, 1986.

[11] H. M. Chawla and K. Srinivas, "Molecular recognition of 2, 6-naphthoquinone by 5,11,17,23, 29, 35-hexa-tert-butyl-37, 38,39,40,41,42-hexahydroxycalix (6) arene," Indian Journal of Chemistry, vol. 32B, pp. 1162-1164, 1993.

[12] A. Ikeda and S. Shinkai, "On the origin of high ionophoricity of 1,3 -alternate calix [4] arenes: $\pi$-donor participation in complexation of cations and evidence for metal-tunneling through the calix[4]arene cavity," Journal of the American Chemical Society, vol. 116, no. 7, pp. 3102-3110, 1994.

[13] Z. T. Li, G. Z. Ji, C. X. Zhao et al., "Self-assembling calix[4]arene [2]catenanes: preorganization, conformation, selectivity, and efficiency," Journal of Organic Chemistry, vol. 64, no. 10, pp. 3572-3584, 1999.

[14] C. Nuckolls, F. Hof, T. Martín, and J. Rebek, "Chiral microenvironments in self-assembled capsules," Journal of the American Chemical Society, vol. 121, no. 44, pp. 10281-10285, 1999.

[15] M. Conner, V. Janout, and S. L. Regen, "Synthesis and alkali metal binding properties of "upper rim" functionalized calix[4] arenes," Journal of Organic Chemistry, vol. 57, no. 13, pp. 3744-3746, 1992.

[16] M. Larsen and M. Jørgensen, "Selective halogen-lithium exchange reaction of bromine-substituted 25,26,27,28-tetrapropoxycalix[4]arene," Journal of Organic Chemistry, vol. 61, no. 19 , pp. 6651-6655, 1996.

[17] C. Y. Huang, "Determination of binding stoichiometry by the continuous variation method: the job plot," Methods in Enzymology, vol. 87, pp. 509-525, 1982. 


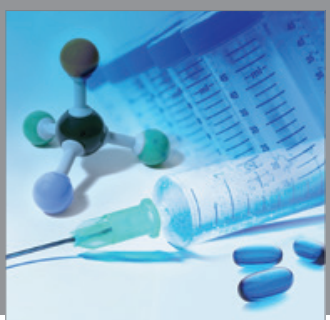

International Journal of

Medicinal Chemistry

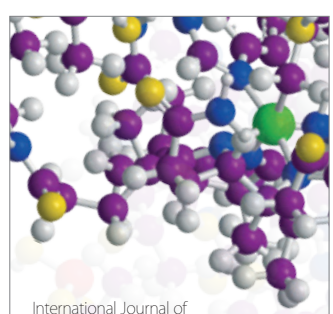

Carbohydrate Chemistry

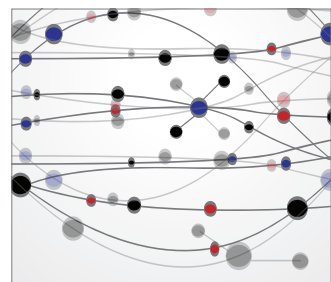

The Scientific World Journal
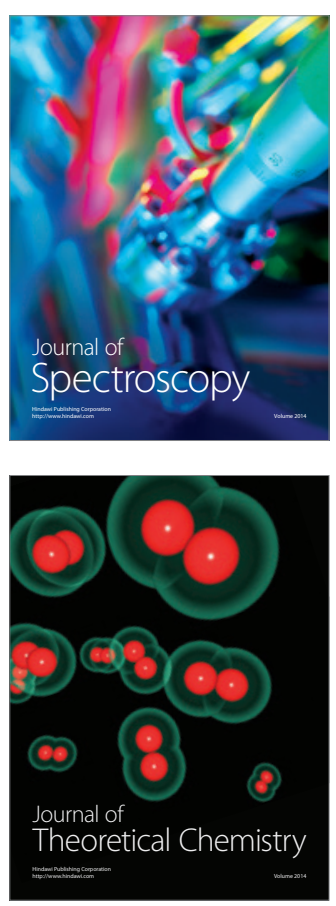
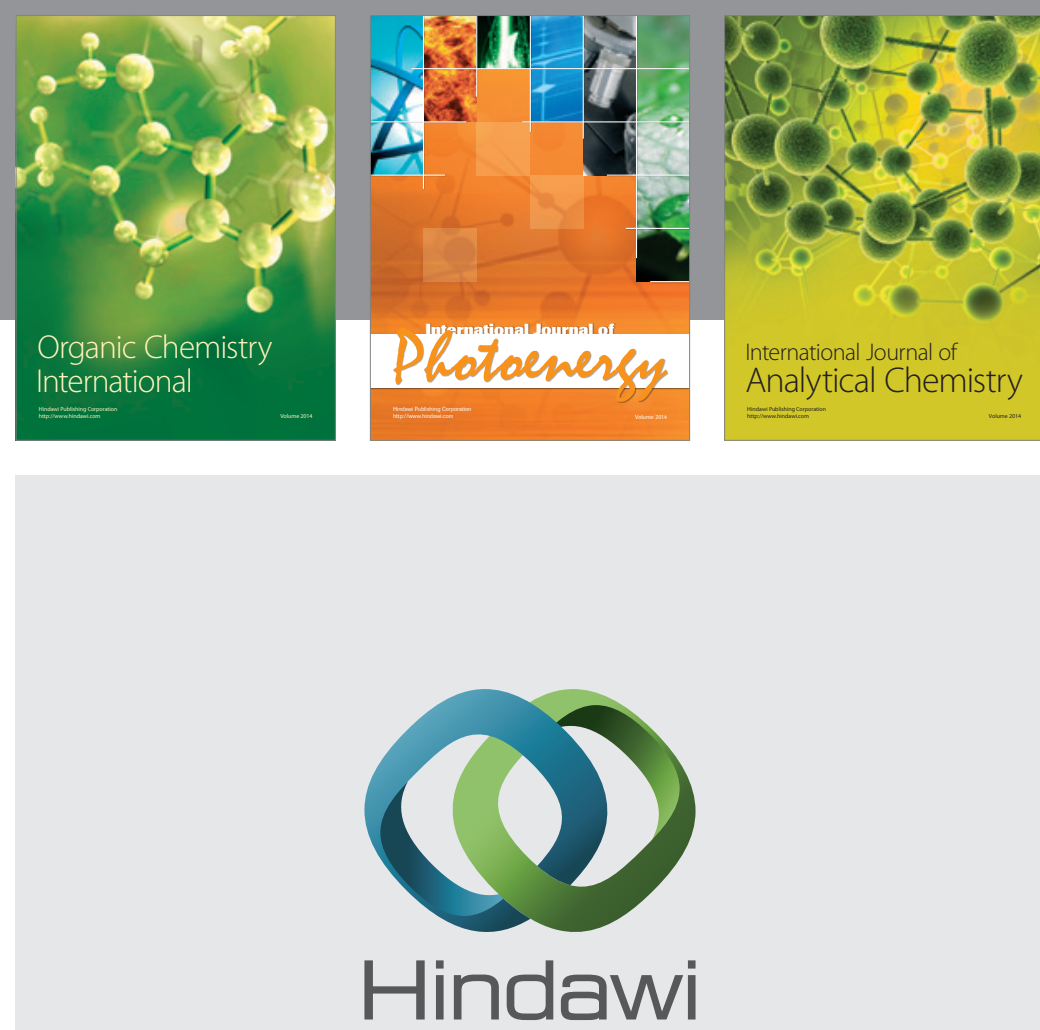

Submit your manuscripts at

http://www.hindawi.com
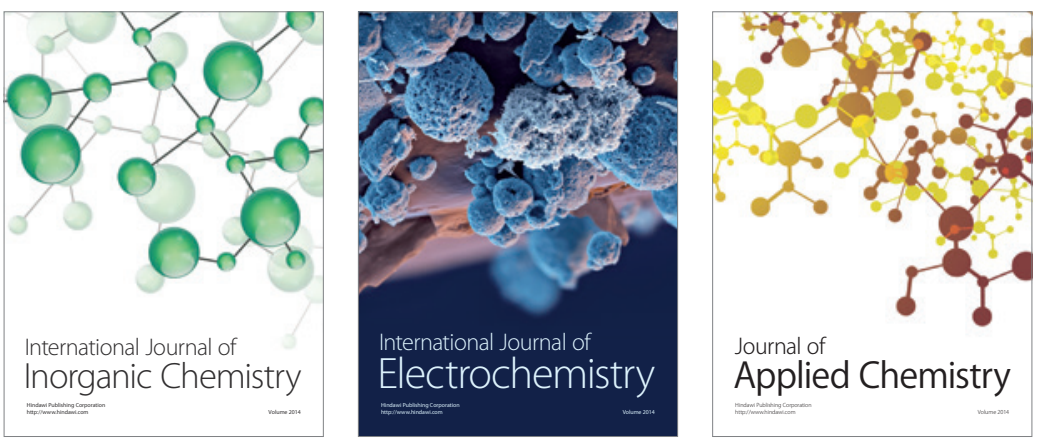

Journal of

Applied Chemistry
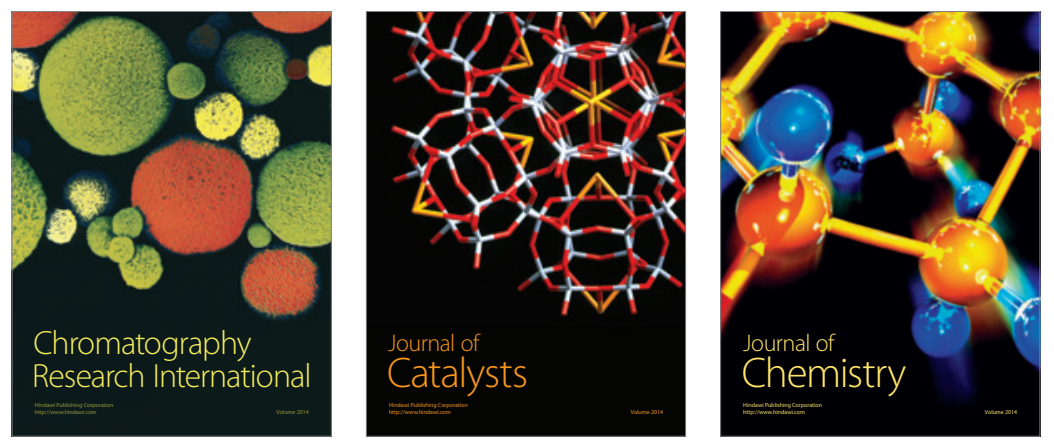
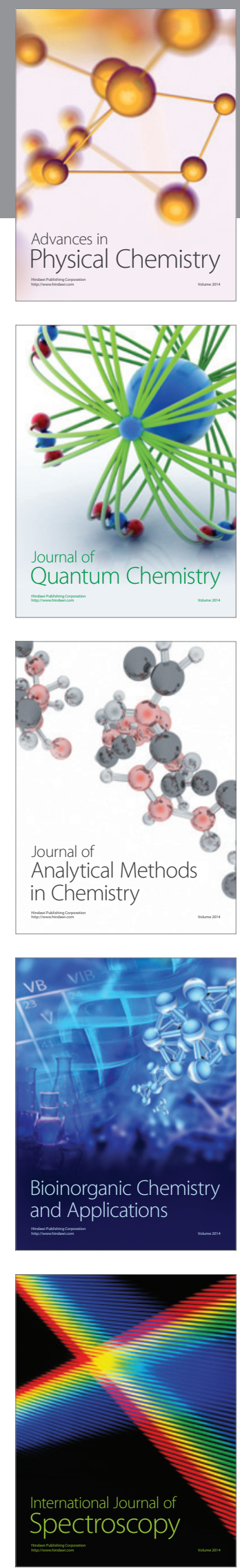